\title{
INSTITUTE OF LAW RESEARCH AND REFORM CELEBRATES TWENTIETH ANNIVERSARY
}

\author{
PETER J.M. LOWN*
}

On November 15, 1967 Dr. Max Wyman, Mr. J.E. Bradley, Mr. John E. Hart, Mr. H.G. Field and Mr. W.H. Hurlburt signed an agreement on behalf of the Board of Governors of the University of Alberta, the Attorney General of Alberta and the Law Society of Alberta respectively. Thus was formed the Institute of Law Research and Reform.

The first meeting of the Board of Directors of the Institute took place on Thursday, November 30, 1967, at which time Mr. H.G. Field was elected Chairman of the Board and Professor A.R. Thompson as Secretary.

Successive quinquennial agreements have been signed by the founding parties, the most recent assuring the continued operation of the Institute through 1992. The three founding bodies, signatories to the agreement, appoint members to the main governing body of the Institute, namely, its Board. Those members co-opt additional members to the Board.

The three parties also provide for the financing of the ongoing operations of the Institute. The University of Alberta provides the Institute with its office premises in the Law Centre at the University of Alberta and with a variety of additional support services including the handling of trust accounts on behalf of the Institute. The University also makes a fixed annual grant to the Institute. The second source of funding is the Department of the Attorney General, which provides approximately 40 percent of the Institute's annual agreed budget. The third and largest source of funding is the Alberta Law Foundation, which provides approximately 60 percent of the Institute's annual budget. Foundation funding was commenced in 1973 on a project by project basis. In 1977 that funding was converted to a block grant toward the Institute's core funding.

The creation of the Institute was a response to concerns on the part of the Law Society that it was not possible to discharge the functions of a law reform agency for the province in an adequate fashion through the law reform committee established by the Benchers of the Law Society. Notwithstanding the considerable effort and even more considerable achievements of that committee which had existed until 1967, the consensus appeared to be that voluntary part time law reform work by members of the profession could not do justice to the needs of law reform. The response was the creation of what has been described as a "novel . . . and .. - unique" body. This body was expected by Dr. Wyman, one of the members of the first Board of Directors, to play "a significant role in both the University and the community".

- Peter Lown is Director, Institute of Law Research and Reform, Edmonton, Alberta. 
The body is unique in that it has the commitment and ongoing support of its founding parties yet has the independence and distance to control its own affairs by reference to the objectives set out in its founding agreement.

The Institute's objectives have remained unchanged since the first agreement in November of 1967, a tribute to the drafting wisdom and foresight of the parties at that time. These-objectives are:

(i) to conduct and direct research into law and the administration of justice;

(ii) to consider matters of law reform with a view to proposing to the appropriate authority the means by which the law may be made more useful and effective;

(iii) to promote law research and reform; and

(iv) for the purposes described in subclauses 1 through 3 to work in cooperation with the Faculty of Law at the University of Alberta, the Faculty of Law at the University of Calgary, and with others.

In practice, the activities of the Institute have centered around three particular areas. The first, the principal law reform function, entails the identification of areas in which reform is desirable; a review of the law to determine whether reform is needed; consultation with affected parties and bodies; and the preparation and delivery of reports to the appropriate authority embodying the results of the Institute studies. The second area of activity is supplementary to the law reform function but equally vital. This second area may include the preparation of draft legislation so as to give specificity to the Institute's proposals; explanation and consultation with members of the public or those affected by the Institute's proposals; monitoring of the implementation of proposals and assistance in education to the profession so as to understand the effect of changes brought about by Institute proposals. The Institute also cooperates with the Uniform Law Conference of Canada, so as to enhance and further the law reform function across the country and to ensure consistency of proposals wherever possible. The Director of the Institute is, as a matter of policy, appointed to the conference by the Attorney General for the province. A third and equally important function is the encouragement of research into law and the administration of justice. To the extent that resources permit, general research apart from specific projects is carried out and the results are made available to the public or to interested groups or parties. To some extent this is also carried out by the encouragement given to individual Institute counsel to pursue their areas of interest.

\section{PERSONNEL}

\section{A. THE BOARD}

The Institute's Board of Directors consists of several statutory members. The Attorney General of Alberta appoints two members, the Law Society of Alberta appoints one and the President of the University of Alberta appoints one. Two further members are appointed by the Faculties of Law at the Universities of Alberta and Calgary, one each respectively. The Institute Director is also a member of the Board. 
Those statutory members of the Board may in turn appoint a further number of Directors, not less than four and not more than seven. The founding agreement contains no prescribed qualifications for Board membership other than the manner of appointment, but it has conventionally been the case that qualified lawyers have been appointed.

Appointments over the twenty year history of the Institute show an attempt to achieve a balance between academic and practicing lawyers and to achieve representation from the various geographic areas of the province.

The Board is a working entity. While it has overall responsibility for policy and planning within the Institute it is deeply involved in the development of law reform proposals. The Board meets monthly as a whole, to discuss both administrative matters and specific projects. It also operates by way of subcommittees appointed to review work within a specific project area. The Board elects a Chairman who presides at Board meetings and acts, in conjunction with the Director, as an external representative of the Institute. The term of Chairmanship is coterminous with membership on the Board.

\section{B. THE DIRECTOR OF THE INSTITUTE}

The Director is the Institute's Chief Executive Officer responsible for management of the day to day operations of the Institute and for reporting to the Board of Directors on those matters.

The founding agreement specifies that the Director shall be appointed jointly by the statutory members of the Institute's Board and by the Board of Governors of the University of Alberta. Where that is not already the case, the Director, upon appointment acquires academic status in the Faculty of Law at the University of Alberta. The Board delegates to the Director the management of the Institute and many of the functions of financial planning. In addition the Director has the role of acting as the public and external representative of the Institute with all aspects of the profession and the legal community.

The first Director of the Institute was Professor W.F. Bowker, Q.C., formerly Dean of Law at the University of Alberta. Dr. Bowker's long involvement in the Alberta legal profession and his national standing as Dean, scholar, and participant in the Uniform Law Commissioners of Canada made him a perfect choice to provide the wise and dedicated leadership that was necessary to set the Institute on its course. Dr. Bowker was succeeded by Mr. W.H. Hurlburt, Q.C., whose own personal stature and reputation for outstanding work for the legal profession allowed him to continue the course which had been set by Dr. Bowker. The work of these two men during the formative years of the Institute, along with the substantial contribution by members of the legal profession has charted a successful course for the Institute.

Two subsequent appointments have been made to the position of Director of the Institute. Professor R. Grant Hammond joined the Institute's staff as Senior Counsel in 1982 after teaching at Dalhousie University, and was subsequently appointed to the position of Director in succession to Mr. Hurlburt in 1985. Professor Hammond returned to his 
native New Zealand as of April 1988 to take up a position at the University of Auckland. The current Director is Professor Peter J.M. Lown who was appointed on April 1st, 1988 after 19 years of teaching at the University of Alberta, and 15 years of membership at the Alberta Bar.

\section{COUNSEL}

The engine of the Institute is its counsel and full time legal staff. The number of full time counsel has varied between five and seven and the volume and quality of work which has been produced is a tribute to the calibre of those who have occupied the position of counsel.

Most of the research and preparation of reports and recommendations for any given project is prepared by an assigned counsel. The specified counsel has the responsibility for designing and implementing the research proposal, reporting on it to the Board and developing the reform proposals in accordance with Board advice and policy. Counsel may also be responsible for carrying out a consultative process both during the time of preparation of law reform proposals and after the publication of reports.

The Institute has also been fortunate in making an arrangement with the Faculty of Law at the University of Alberta, through which a senior staff member may be seconded to the Institute for a period of up to two years. The arrangement, which is of mutual benefit to both Institute and faculty, has seen Professor C.R.B. Dunlop do major work in the creditors' rights area, Professor C. Davies prepare a report on cohabitation outside marriage, and Professor P.J.M. Lown commence work on an electronic registry of corporate securities.

The current counsel are Ms. Margaret Shone, Mr. Brian Burrows, Mr. Richard Bowes and Mr. W.H. Hurlburt, Q.C.

\section{MODE OF OPERATING}

\section{A. APPROVAL OF PROJECTS}

Since the Institute is founded under a joint venture agreement, with stated objectives, it has no statutory basis, and is therefore able to choose its own law reform program. Each project requires the specific approval of the Board of Directors, after due deliberation as to the objectives of the project, the resource implications of assuming it, the likelihood of its producing distinct and worthwhile changes in the law, and any other relevant matters.

As a general approach, the Board first examines a report setting out how the feasibility of a project is to be examined. The Board will then authorize sufficient preliminary work to be done to determine whether the project will succeed. After a review of the objectives sought to be obtained by the project and the implications of assuming it, the design of the project may be approved. Ultimate legislative implementation is not the sole criteria for approval of such a project. On occasion a leadership role may be required in law reform, or the generation of information for the public may be important.

Suggestions for reform topics come from many sources. Direct suggestion, or the assumption of a topic with the overt encouragement of a 
government department has often occurred. Major statutory enactments such as the Matrimonial Property Act or the Business Corporations Act were carried on in this fashion. Members of the Board and legal counsel may often draw on their own experience to determine which areas of law are ripe for reform. Finally, members of the profession, either individually or through formal bodies such as the Law Society or the Canadian Bar Association can and do make suggestions for reform.

The Institute is open to all such suggestions and does not have a predetermined approach to the selection of projects. It has tended to be pragmatic and to select projects which are thought to raise contemporary and compelling concerns which may be addressed in a manner which will result in practical proposals for reform. Areas of interest have varied over the Institute's history, and partially reflect the mood of the time and the expertise of Institute staff. For a time, several areas of family law occupied the attention of the Board, to be succeeded by major interest in the corporate commercial area. Of late the largest project has been a complete review of the area of creditors' rights. Most recently, concern with respect to the administration of justice, the costs and time of litigation has begun to emerge.

\section{B. TYPE OF PUBLICATIONS}

While nomenclature has changed over the last 20 years, the Institute publishes four kinds of documents, incorporating its work product. The earliest stage of publication is that of a Research Paper. These publications will be preliminary documents containing the results of research, usually of a doctrinal or empirical nature. The impetus for publication of such a work is that the research was necessary in the initial stages of a project and it is thought that the availability of the material in published form to other researchers is of some importance.

The second stage in publication is that of an Issues Paper. These publications are designed to provide a certain degree of information about the subject area under consideration, to suggest the kinds of questions which the Institute thinks ought to be investigated and possibly to give some tentative views on solutions. In most cases, Issues Papers will be published in conjunction with a defined consultative process.

The third publication is a Report for Discussion. This report corresponds most closely to the title of Working Papers, which are commonly produced by other law reform agencies. A Report for Discussion will contain a full description of the law, and detailed analysis of the identified problems, and will propose some relatively well developed suggestions for improvement or reform of the law. A Report for Discussion may or may not include draft legislation. Where the Report for Discussion has not been preceeded by a Research Paper or an Issues Paper, the report will record much of the Institute's research so as to make it available to a wider audience.

A Final Report embodies the results of the Institute's deliberations and will usually be accompanied by specific proposals for reform. While differing views and opinions will be reflected and commented on in the report, the document itself will result in one final institutional conclusion 
or recommendation. It is quite common to include suggested draft legislation, so as to provide specific proposals to the appropriate authority.

\section{CONSULTATION}

The same concern which led to the formation of the Institute and the transfer of responsibility for law reform from a part time committee, has led the Institute to involve itself in formal consultation both at the prereport and the post-report stage. The Board of Directors has begun to appoint subcommittees to participate in specific projects, the intention being that such subcommittees would draw membership from those most skilled in a particular area under review, and would also be able to identify the areas in which consultation or information should be sought. It is quite common for Institute counsel to prepare a directory of interested and concerned persons and bodies who should be kept informed of the status of the research throughout the project.

At the report stage, formal arrangements may be made to ensure that there is proper feedback to the questions posed or proposals made for reform. Most recently this has taken place in the two reports entitled Sterilization Decisions, Report for Discussion No. 6 and Cohabitation Outside Marriage, Issues Paper No. 2.

\section{PUBLICATIONS}

The Institute produced Report No. 50, Prejudgment Remedies for Unsecured Claimants, in February of 1988. In addition, six Reports for Discussion and two Issues Papers had also been published. This does not include the various Research Papers which have been made available.

This rate of production, and the volume of legal research involved in it, is an impressive measure of the twenty year history of the Institute. The general areas covered by these reports have touched on occupiers liability, perpetuities, maintenance and enforcement, contracts, evidence, matrimonial property, landlord and tenant, builders' liens, defamation, corporations, sale of goods and many other areas. The record of publications is both eclectic and comprehensive.

Of those fifty reports, thirty four have been implemented in one or other legislative form and several are still under review. The choice and design of projects by the Board of Directors, and the care taken in the process, is underscored by an implementation level of close to seventy percent. This level, it is asserted, is a mark of the sensitivity of the Board and counsel to the need for reform and the proposals which meet that need. Nor could it be critically asserted that the projects show a predilection for safe and noncontroversial topics. The fifty topics upon which formal reports have been issued neither lack significance nor attached diversity of opinion. ${ }^{1}$

The most recent activity of the Institute has centered around several areas. In August of 1987, Report for Discussion No. 5 was published dealing with Financial Assistance by a Corporation and the provisions of

1. A complete list of the fifty reports and consequent legislation is contained in the 1987-88 Annual Report, published on March 31, 1988. 
Section 42 of the Business Corporations Act. This section regulates the conditions under which a corporation may give financial assistance, directly or otherwise, to a shareholder or director of that corporation, where there are reasonable grounds for believing that the corporation may, as a result of the financial assistance, be insolvent or not liquid. The section has given rise to problems in practice and has attracted adverse comment from various parts of the Bar and financial community. The Institute is currently reviewing submissions which were made on its draft report.

Formal consultation sessions have been held on the area of Sterilization Decision for Minors and Mentally Incompetent Adults. This subject was dealt with in Report for Discussion No. 6 published in March of 1988. The report sets out the guiding principles which ought to be followed in such sterilization decisions. It also provides guidelines for the kind of decision which was dealt with by the Supreme Court of Canada in its decision in the case of Re Eve. ${ }^{2}$

Issues Paper No. 1 published in July of 1987 makes a proposal for a complete review of the existing Alberta Arbitration Act. This review will provide for streamlining and clarification of the arbitration process, and a clear statement of the circumstances in which there may be court intervention in the arbitration process.

In response to concerns as to the phenomenon of cohabitation by unmarried persons, the Institute undertook a review of the law relating to cohabitation outside marriage. Initially an empirical and statistical survey was conducted to determine the incidence of cohabitation and the views of cohabitants as to their relationship. Subsequently a comprehensive review of a wide array of legal aspects of cohabitation was undertaken. Expert consultation was conducted in March of 1988 and a final position will be taken by the Board in the fall of 1988.

Major work continues in the area of creditors' rights with a complete review of the prejudgment and post-judgment remedies of a creditor to pursue and enforce obligation, and to execute in furtherance of those rights. This comprehensive review must dovetail with the recently introduced proposals for implementation of a Personal Property Security Act, and the amendments to the Land Titles Act proposing an abolition of the general registry system. In scope and complexity this is one of the larger projects which the Institute has undertaken.

Work proceeds in other areas including the area of mortgages, electronic clearing agencies for corporate securities, limitations and the responsibility of corporate directors. New initiatives are being designed in the dispute resolution area and some areas of health law.

\section{FUTURE ACTIVITIES}

It is always possible to underestimate the cost and time involved in a thorough review of an area leading to law reform proposals. While, in some cases, the area may be discrete and capable of review within a 
comparatively short time, it is becoming increasingly apparent that many areas are complex and have subtle interstitial connections with other areas of the law. This is equally true of projects which have ramifications in areas which are outside the exclusive jurisdiction of the provincial legislature.

One pressure which the Institute will face is the necessity to design projects within manageable proportions and within manageable time frames. Large projects demand the dedication of substantial resources, are difficult to manage, and may tend to take on a life of their own. The challenge to the Institute is to move into these areas in a planned and organized fashion which will allow the progress of the project to be monitored and the proposals for reform to be presented in an orderly and digestible fashion.

This is equally true in areas which require cooperation between the Institute and the Law Reform Commission of Canada and in areas of interest to the Uniform Law Conference where a broader consultative basis and consistent national treatment is necessary. Several projects have been conducted successfully to date, namely, the protection of trade secrets report, a cooperative project with the Law Reform Commission of Canada in which the Institute played a lead role. A further example is the proposal of a Uniform Mental Health Act where Institute personnel have been members of working groups of the Uniform Law Conference of Canada.

A second challenge to the Institute is to ensure that it carries out the consultative process, both with the profession and with the public, in a manner which contributes constructively and positively to the formation of proposals and contributes to the acceptance of the proposals at the time of issue. In complex areas, there may also be an educational role to be played by the Institute in explaining the implications of law reform proposals to affected persons.

\section{CONCLUSION}

In April of 1988, the Attorney General of the Province of Alberta hosted a dinner at Government House in honor of the twentieth anniversary of the Institute of Law Research and Reform. Present at that dinner were Ministers of the Crown, members of the judiciary at all levels, representatives of the founding parties, and an array of people who have been associated with the Institute in one way or another. The Attorney General reviewed the contributions of the Institute to the legal community over its twenty years of existence.

Perhaps the most appropriate mark of the anniversary of the Institute and its contributions during the time of its existence is that by dint of publications of high calibre, practical application and broadly acquired knowledge, it is now recognized as a leader among law reform agencies in the country, an integral part of the legal community within the province and a repository of solid legal research. The challenge to the Institute is to continue and build on that reputation which has been established. 